DINAMIKA ILMU

Vol. 19 No. 2, 2019

P-ISSN: 1411-3031; E-ISSN: 2442-9651

doi: http://doi.org/10.21093/di.v19i2.1717

\title{
Innovation of Learning Management in Madrasah Level
}

\author{
Zamroni \\ State Islamic Institute of Samarinda, Indonesia \\ e-mail: zamroni7502@yahoo.com
}

\begin{abstract}
The presence of Islamic education i.e. madrasah has significantly contributed to the live of public citizen in Indonesia. Therefore, the existence of madrasab education develops in accordance with the needs and demands of society today as well as it be able to adjust the existence of the industrial revolution 4.0. The development madrasab education must be done by increasing the quality of human resources, redesigning curriculum development and managing the quality of learning. In this context, as an effort to achieve the above educational goals, new breakthroughs in the field of learning are needed i.e. continuous quality improvement by carrying out various approaches, especially in the field of learning management innovation in order to drive the Islamic education as a central for excellence where the students are able to compete in the midst of the 4.0 industrial revolution era. The existence of learning management essentially aims to build and develop the full potential of learners, and these efforts can only be made if all learning activities are programmed in accordance with the needs of students, parents, and society expectations. Therefore, at the practical level, learning activities are understood to be able to run effectively and efficiently if all of the above activities start from the managerial process, through the learning planning process; learning management; management of students management of quality human resources or professionalism of teachers; development of learning activities and the process of evaluating good learning.
\end{abstract}

Keywords: industrial revolution 4.0, Madrasah education, management innovation 


\section{A. Introduction}

Sociologically, the presence of Islamic education madrasab has significantly colored and made various contributions in Indonesia (Fauzi, 2018). Therefore, the dynamics of madrasah education tries to follow the needs of learners and social demands by making various changes, especially in the field of learning management, in accordance with the challenges and the existance of 4.0 industrial revolution. In addition, there are three aspects relate to development of learning management i.e. are, increasing human resources, curriculum and learning quality management. Those elements are definitely aim to enhance the competitiveness of madrasah education in entering the industrial revolution, 4.0 where the portrait of madrasah is also believed to be a stronghold of morals and become a human and capital realizing the future, so that its existence continues to play its role dynamically to face this technology era (Zahroh, 2014). In line with Zahroh (2014), Anwar (2018) also points out that madrasah has a vital function especially in building character of becoming students who have critical attitude. However, many facts show that we have to face there are still many educational institutions still have to figure out problems in 4.0 industrial revolution era (Ajmain, Hehsan, \& Mohamad, 2019). It is because 4.0 era means there is association between education itself with high intensity of technology usage. As stated by Shamim et al. (2016) that 4.0 industrial revolution is connecting machine such as Cyber Physical Systems (CPS) to learning implementation. In other words, interference of 4.0 industrial revolution in deeper meaning is an advancement to all elements from traditional or manual methods to the modern one by optimizing the usage of technology such as virtual learning such as chatroom though certain software or application (Shahroom \& Hussin, 2018). Not only students who are still studying in madrasah, soo when they graduate from madrasah aliyah they need are expected to compete in industry 4.0 by facing digital world. Therefore, curriculum of madrasah need to be innovated to meet the demand of 4.0 industrial revolution (Nurcholiq, 2019).

Without leaving aside the importance of madrasah education in relation to industry 4.0, nevertheless, the existence of madrasah education in various area in Indonesian education, since the last few decades significantly has shown significant progress in improving the quality of education by creating new ideas in the field of management of Islamic education in general, including improving learning through learning management innovations i.e. innovation in branding the madrasab education, innovation in welcoming students, innovation in curriculum, and innovation in learning (Sofanudin, Rokhman, Wasino, \& Rusdarti, 2016). In this context, the manifestation of learning changes has generated madrasab education models, such as superior madrasah, models madrasah and favorite madrasah. Therefore, changes in learning and the implementation of madrasah education are essentially part of global changes in various sectors, especially in the field of madrasab in improving the quality of graduates, so that the existence of madrasab still survive. In other words, the significance of the changes referred to, in essence cannot be separated from the existence of competition (positive competition) between education that is praxis to meet future needs (Fauzi, 2018).

To go further, Islamic education has now entered global competition which requires quality improvement with ready graduates to enter the workforce. This can be achieved well if madrasab leaders and teachers modify learning models in order to have effective learning. It is in line with the standards of providing education such as; management standards, curriculum, finance, content, infrastructure, graduates and education personnel. The standardization of education management is basically understood as the basis of educational activities and 
implementation including the planning, implementation and supervision processes in learning by taking into account local, national and global changes (Mulford, 2003). Besides, education management standards in general are the basis for determining the minimum criteria and completeness in the field of management that shows certain educational institution has high quality. It is indicated by remarking achievement in academic field, having awareness and being responsible towards community and government in terms of education management.

In this context, as an effort to deliver the quality of madrasah education, it must get support from various elements i.e. strong leadership of professional educators, the role of the madrasab committee in order to create an effective organizational environment by working together to be able to build goals of madrasah (Iswan, 2015). Therefore, the existence of madrasah education is currently getting enough attention among public society, as this is evidenced in the selection of madrasah education since the last few years where madrasab has growing up until now (Rosyada, 2017). In addition, madrasah education is also believed to be the last moral defender that can integrate religious and general knowledge in learning activities. Above goals of having quality of madrasab only can be gained though managament of change, by implementing learning management innovations, even seen as a new revolution in improving the quality of madsarah education (Fauzi, 2009). The portrait of madrasah education is essentially born as a forum to bridge graduates who are not only able to prioritize intellectual intelligence, but also emotional and spiritual intelligences.

\section{B. Learning Management Innovation Paradigm}

Management in context of education can be seen from several point of views that have been developed in society's paradigm. At the practical level, as an effort to realize superior madrasab education certainly cannot be separated from managerial aspects in various learning activities, one of which is through planning, organizing and evaluating the program. Therefore, management is basically understood as one of the efforts to achieve the goals according to the program set in the context of learning (Mulyadi, 2010).

Learning management activities in other dimensions are interpreted as the process of utilizing various potentials in making new innovation in the field of learning to face challenges as a result of internal and external changes in the organization, with the aim of developing madrasah quality through goal-oriented planning. As explained by Syafaruddin (2005), management is the performance of giving desired results by means of grooves efforts consisting of utilizing human talent and resources, management activities are part of the ability to direct, mobilize and utilize all the potential resources that exist in the learning process. While in other fields, management is understood as a series of activities directed at resources within the organization, namely Islamic education through the process of planning, implementing and evaluating in the field of learning (Fatkuroji, 2012). Therefore, improving the quality of madrasah is the responsibility of a leader, by carrying out various changes in the context of learning in accordance with school programs (Bafadhal, 2014).

In addition, improving the quality of Islamic education is basically an important part which can be done through various learning activities that are innovative and oriented towards effective learning. Therefore, the essence of learning is expected to increase students' understanding through school programs and to improve learning activities. Thus, learning management is a series of processes for achieving goals in accordance with previously planned programs, through the utilization of human resources besides doing a process of continuous 
improvement in accordance with the objectives of madrasah education by focusing on customer satisfaction in the field of education quality (Mukhtar, Anwar, \& Kholilah, 2019). In this case, learning management in madrasab education was built as part of quality improvement, in accordance with the development of the industrial revolution 4.0. In short, improving the quality of madrasah is a major factor in the management of education where it needs a new perspective in the management of education, especially in the field of learning through changes in paradigm and orientation of learning today.

Furthermore, the existence of learning is essentially aimed at developing all the potential of students, both cognitive, affective and psychomotor. These efforts can be carried out effectively if all learning activities have been programmed properly according to the needs of the public society. The approach of conducting learning activities must be changed from teacher centered becomes student centered (Emaliana, 2017). Not only the learning approach, the learning model also needs to be changed from conventional to direct instruction, cooperative learning and problem-based instructions (Loyens, Magda, \& Rikers, 2008; Davidson \& Major, 2014). Those efforts are potentially drive to education of madrasab which is ready to face the 4.0 industrial revolution (Farikah, 2019).

To deeper discussion towards learning management, it is essentially a combination that consists of various elements which relate one to another, through the process of planning, implementing, organizing and evaluating to help learning activities so that they can run effectively and efficiently (Lubis, 2018). In this case, the role of human resources in learning activities becomes an important part in optimizing the learning process supported by various other components i.e. school facilities, conducive classrooms, professional teachers and active learning methods, (Hamalik, 2002). Moreover, all learning activities must have curricular objectives that must be able to integrate institutional goals. In this context, institutional objectives must be in accordance with the vision, mission and institutional goals, which are related to the dynamics of latest education paradigm i.e. the 4.0 industrial revolution (Mulugeta, 2015; Aithal, 2015). Therefore, as an effort to realize and achieve the intended goals, of course an innovative learning management system is needed. The above views as explained in several previous studies which one of them is Yusuf et al. (2014) where they investigated about management of education in public schools, explained that the realization of education basically cannot be separated from management through; planning, organizing, actuating controlling in every school program. Whereas Rahmah (2016) also has done a research on renewal learning management which explained the success of learning in essence built from regeneration of innovation in learning, starting from the learning paradigm, the implementation and evaluation of activities as part of achieving the institutional vision and mission. In this context, the development of madrasab education quality can be realized if every program always uses a management system. Therefore, the quality of madrasab education can be measured, if the management system is intended to change in order to have more qualified learning management (Muhaimin, 2003), as this is described on below figure: 


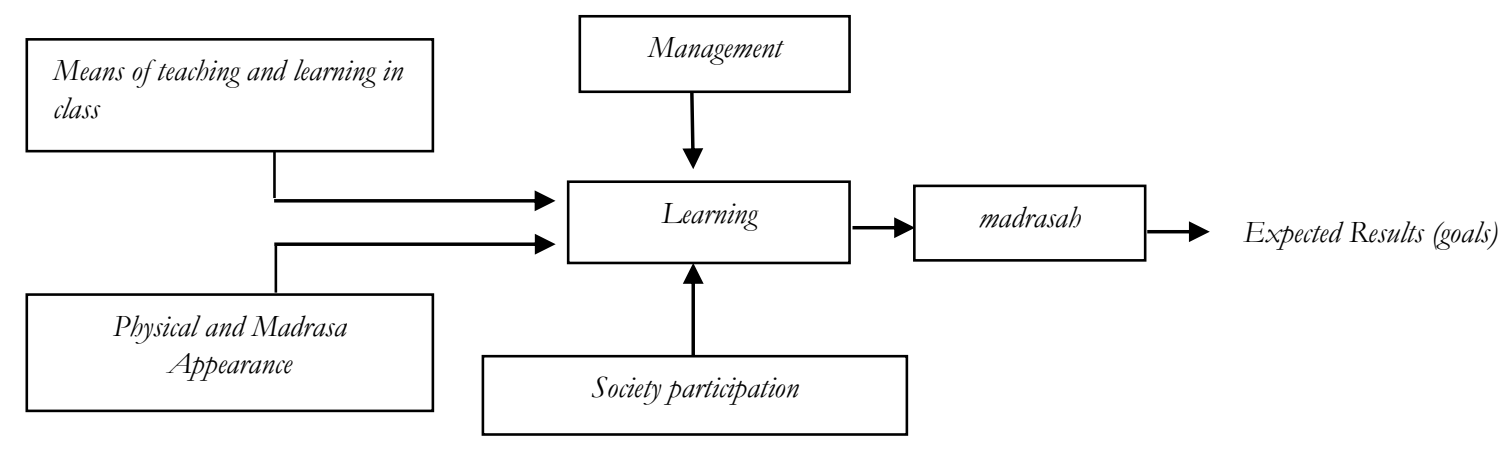

Figure 1: Management System

From broad explanation above, learning management has various functions and strategic positions in developing the quality of madrasab i.e. through innovative learning activities. Therefore, to achieve effective and efficient learning, the existence of qualified management is on the top priority in order to actualize madrasah education goals.

\section{Learning Components in Improving Education Quality}

Learning management is essentially an important part of the learning process. It is a series of activities that are designed and developed to achieve learning objectives optimally. In order to achieve these objectives, several strategic steps can be carried out, namely; identify students' needs, formulate learning goals, analyze the need to transform into learning objectives, design learning methods and materials, carry out learning activities and conduct learning assessments (Hamalik, 2002). In this context, learning management is understood as one-piece through a process of interaction between one component to others i.e. students, teachers, objectives and learning materials (Amin, Siswanto, \& Hakim, 2018).

Above four components, students are placed as the first component in learning where their presence is the key to all implementation of education, so that there is no learning activity without students. In another aspect, students are unique individuals where they can interact with their peers, teachers, and to social community in general sociologically. The existence of students brings potentials with a variety of different social backgrounds. This aspect becomes a potency that must be optimally developed through learning activities (Sardiman, 2001).

Not only students, the role of the teacher also occupies a strategic position in developing the quality of education through an innovative learning process (Hamalik, 2002). The presence of teachers in education is understood as professional staff, and has a strategic role in improving quality. The teachers must be able to master a set of learning activities which are known as teacher competence. In general, these competencies include the ability to guide students, master learning objectives and methods, assessment techniques and learning environment (Lubis, 2018). Besides that the teacher has several important roles in learning activities i.e. as a demonstrator, instructor, mediator and facilitator, and as a motivator (Syafaruddin, 2005). In line with Syafaruddin (2005), Rindu \& Ariyanti (2017) also point out teachers' role in teaching and learning process i.e. teacher as a controller, assessor, organizer, motivator, participant, informaer, facilitator, demonstrator, and a guide. To sum up, it seems never been so easy about being a real teacher because teachers have to act with so many characters and roles depending on class condition and students' level. 
In addition to those two components, the third is learning objectives where every learning cannot be separated from it. In this case, the teacher is expected to be able to understand the educational goals starting from national education goals, institutional and curricular goals, and general to specific learning objectives. Thus the purpose of universal education and overall learning must be mastered by teachers and arranged based on the characteristics and development of students in the process of learning activities, including knowledge, skills and attitude formation (Sholikah, 2017). The fourth component is learning material which includes the entire material in the implementation of learning. Particularly, appropriateness of the materials also becomes an important part in teaching and learning process since teachers have to make sure whether the materials given is too easy or too difficult.

The next important component is learning methods which are used as techniques for delivering learning materials. In addition, learning methods is not merely about how to deliver learning techniques, but teachers also need to pay attention to media which is appropriate to topic being taught. After recognizing to the suitable learning method, evaluation activities are also urgent matter to be provided to assess students' abilities. These activities must be carried out comprehensively, objectively, cooperatively, and effectively. In addition, evaluation activities are used as a guide to the objectives and learning material, where the teacher must conduct an evaluation by first being able to set standards for the success, ability and completeness of their students (Sa'dun, 2016). The last component is regarding with learning environment where it includes several aspects i.e. physical, social, and psychological environment at the time the learning is taking place.

Particularly, above important components must be managed properly through learning management in order to optimalize learning activities in classrooms as well as achieving learning objectives. In other words, managing the learning environment is not an easy task to do, therefore, teachers must be able to understand the implementation of good learning management which is in line with the indented goals. In addition, the learning components should cooperate each other to result a qualified learning process. Dialogically the interactive relationships of these components can be described as follow:

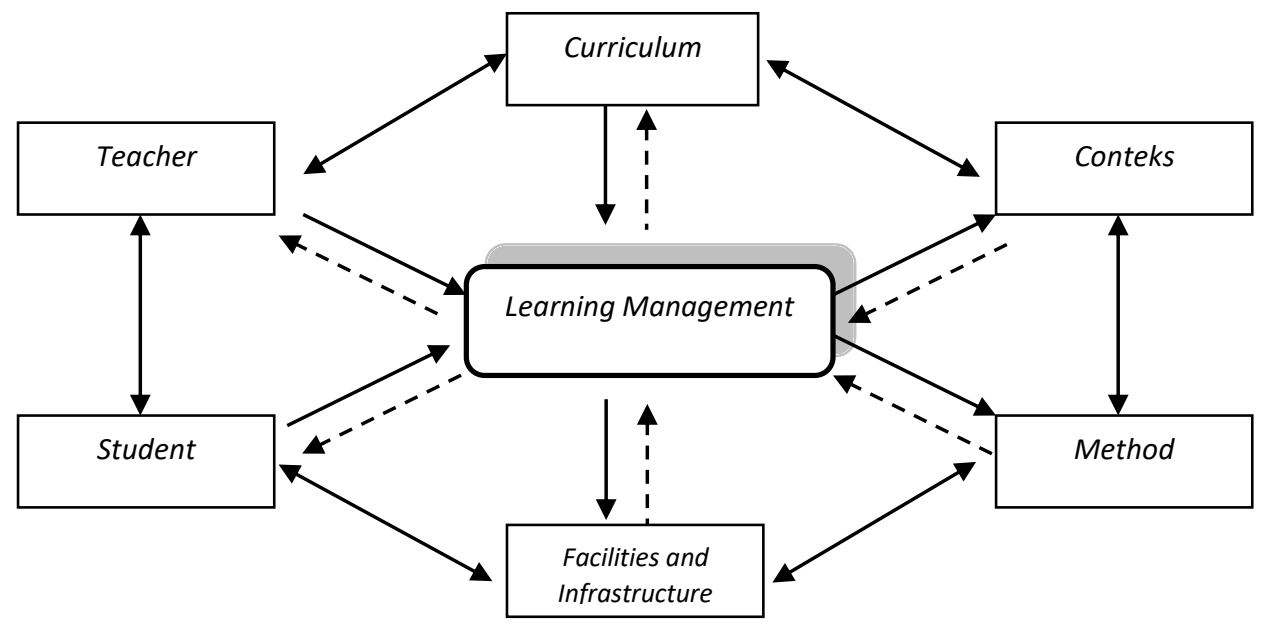

Figure 2: Interactive Relationship Learning Management 
Above figure indicate that those components become very important to realizing the learning quality as well as pay attention to students' development while considering their learning needs. It is very important to highlight that teachers' roles got the very urgent position in rationalizing the learning process where teachers need to provide students with sort of learning experiences, involvement, and learning resources (Bolhuis \& Voeten, 2001).

\section{Essential Aspects in Learning Management Innovation}

At practical level, learning management can run effectively and efficiently if all programs in learning activities start from the managerial process. The first aspect that needs to be done is learning planning. In this case, every learning program needs plans so that all activities can be directed based on the intended goals. Planning is prepared as a guide for program implementation where it is essentially a basis for controlling various activities exist in learning management in order to have the learning objectives achieved (Rahmah, 2016). In line with Rahmah (2016), Daryanto (2013) agreed that learning planning is a process where teachers guide, assist, direct the students to have learning experiences to promote various learning skills. Other than that, every activity in the learning process requires a decision making regarding with the actions to be taken in the future (Sudjana, 2000). Therefore, strategy to improve power of making decision independently is very important in management of madrasah (Badaruddin, 2018).

In order to have a good learning management, teachers should take sort of strategic steps i.e. estimating the future, analyzing the educational environment, formulating operational goals, collecting data or information, formulating and determining alternative programs, setting estimated program implementation and preparing program implementation schedules (Brews \& Hunt, 1999). In this case, the effectiveness of having good learning implementation in classrooms depends on how the learning process is planned, where somehow it should predict future activities which probably done by teachers and students. In addition, budgets, procedures, rules, methods, and criteria of achieving intended learning goals must be set up in a learning planning (Linhares, 2009). The school manager needs to pay full attention to those aspects because the success of the implementation of an activity is determined by the merits of planning. In other words, by having those set aspects, school manager can decrease the risk of failure happened during the learning process (Woods \& Cook, 2002).

Not only learning planning, the role of principal of madrasah also determine a good learning management. A principal, of course must be an agent of applying madrasah vision and mission which should be in line with current development which is 4.0 indutrial revolution. As a research conducted by Mulford (2003) where a school principal is one of school leaders who has direct influence to organizational learning and responsible to what happened in school operation such as students, teachers, goals, materials, methods, and evaluation. The principal of madrasah strives for the effectiveness and efficiency of learning management so that all learning objectives can be achieved properly (Muhammadi, Charil, \& Yahya, 2015). Even how teachers and students can make sure they can face educational challenges as well as how they are motivated in doing their parts become the responsibility of the principal (Keller, 1979).

To go further about job description of being a principal is included to students matter directly i.e. admission of new students, coaching students in schools, and strengthening students' programs. In this context, the position of students in the learning process occupies a strategic position, where the presence of students in the learning activities in the classroom has 
brought a number of abilities which significantly different from one to another (Bafadhal, 2014). The above view requires the teachers to help principal to be able to manage learning activities as well as possible through learning management so that the implementation of learning can run effectively and efficiently.

However, by saying a position of school principal in madrasab is very important does not mean there is no challenging matters occurred. Several factors such as social, system, and conflict happened at school are possible to start the engine of what so called by challenges. Because of those factors, the position of becoming a school principal is assumed to be a head of certain school institution who is expected to make the school developed very well. That matter is highly possible to drive the principal becomes stressfull because of that kind of demand which is usually appears from school manager or from parents (Mulford, 2003). To overcome above problem as well as other possible conflicts, one of researchers i.e Badaruddin (2018) has conducted a research on Madrasah Based Management which aim is to provide madrasah with possible step on arranging and managing school funds and determine the school needs autonomously. Particularly, Madrasah Based Management intends to reach productivity of madrasah and satisfaction of customers (students and parents). In addition, good learning planning as explained previously also needs to be supported by a good communication where the management of learning is basically a process of organizing the interaction of students with educators and learning resources in a learning environment within the school.

After ensuring madrasab has well prepared learning planning and recognizing sort of job description of madrasah principal, increasing teachers' professionalism of madrasab education institutions through various trainings also becomes important part in a learning management. so that teacher performance will improve this view, as stated by Laeham and Wexley; performance appraisals are crucial to the effectiveness of management of an organization's human resources, and the proper management of human resources are critical variables affecting an organization's productivity, where individual productivity can be judged by what the individual does in his work, namely how he shows work or the performance. In order to encourage the improvement of teacher professionalism (Fauzi, 2018). This view is also explained in the National Education System (2003) number 20 article 35 paragraph 1 explains that National education standards include facilities and infrastructure, management, funding and assessment of education which must be continuously improved in a planned and periodic manner. The standard in this case is a criterion that has been developed and established by the program based on effective sources, procedures and management. Therefore, the competency of every teacher shows their quality as a real teacher, where the ability can be realized through the mastery of knowledge and professional actions in carrying out its function as a teacher, especially in the learning process. These competencies include the process of learning management; preparing learning plans, implementing teaching and learning interactions, conducting assessments of student learning achievement, implementing follow-up assessment results; potential development, namely professional development; academic mastery includes; understanding of educational insight, and mastery of learning materials (Tremblay, Lalancette, \& Roseveare, 2012).

The next aspect in learning management innovation is the development of preparation in learning activities where the role of teachers must pay attention to interests and attention of students (Harackiewicz, Smith, \& Priniski, 2016; Beckman \& Barry, 2007). In this case, the role of the teacher is not only as a transformer, but must act as a motivator that can arouse learning enthusiasm, as well as encourage students to learn by using a variety of media and learning 
resources that are appropriate to the abilities and abilities of students (Rindu \& Ariyanti, 2017). Therefore, in order to develop the learning process activities, teachers must pay attention to several principles i.e. the clarity of formulation of competencies and teaching preparation, the activities arranged and developed in teaching preparation must be matched the competencies that has been determined, the teaching preparation that is developed must be completed and comprehensive, and there must be coordination between the implementing components of the school program, especially when learning is carried out in team teaching (Mulyasa, 2004).

Moreover, management of learning activities should be able to produce learning quality where it requires various efforts made by teachers and principals. Therefore, the role of the principal and teacher must be able to manage the seven learning components i.e. students, teachers, learning environment, teaching materials, learning methods, and learning media. The purpose and evaluation if we look further have included in the management of teaching and learning activities. Thus the teacher practically must understand and have a high sensitivity to immediately find out whether the learning activities can run effectively or not. In this context, to anticipate these failures, the teacher must prepare some concrete steps, namely making plans to be implemented in teaching and learning activities; change the learning paradigm from especially those concerning the teacher's role; being critical, creative and productive; changing the pattern of actions of students as consumers in a new direction the role of students as producers; creative to produce educational work such as: the creation of learning aids, the analysis of teaching materials, the preparation of various assessment tools and so on (Karli, 2004).

Seventh; learning evaluation; evaluation, measurement and assessment activities. Evaluation according to Kourilski is the act of determining the degree to which an individual or group possesses a certain attribute, it is an act of determining a certain degree of mastery by an individual or group. The evaluation process is generally student-centered. This means that the evaluation is intended to observe student learning outcomes and try to determine how to create learning opportunities. But the evaluation is also intended to observe the teacher's role, specific teaching strategies, curriculum materials, and principles applied in teaching,(Lee, Lee, \& Kim, 2019). In evaluating learning which is often used as an object is a student, when in fact the teacher is also a learning component that is directly involved in teaching and learning activities. According to Krajeweski in Bafadhal, there are two assumptions that underlie supervision, among others a) learning is a very complex activity that requires careful observation and analysis. Through this observation and analysis, an education supervisor will easily develop the teacher's ability to manage the learning process, b) the professional teacher wants to be developed, requiring a way of peer rather than an authoritarian one (Ilyasin, 2017).

In this context, evaluation is an activity that has dimensions at a time that determine success or failure. The above view as stated by Gagne in Hanim, that evaluation is one of the tasks that must be carried out by a teacher to determine how far the success of students, (Hanim, 2019).In other aspects, evaluation activities on learning are more directed at several aspects, including; 1) in the field of teaching, used as a basis for making decisions about what teachers must teach, about what students have learned. Measurement and evaluation must be able to determine competencies, learning content and special skills; 2) learning outcomes, measurement and evaluation are not only used to determine the level of understanding and mastery but also provide an overview of the achievement of the learning program as a whole, 3 ) diagnosis and improvement of learning, in the context of the above difficulties in learning must be sought as well as various alternative solutions. Difficulties can basically be caused by a lack of 
learning content both concerning the material, strategies and learning methods. Therefore, diagnostic test activities can provide a picture of the weaknesses and strengths of students in mastering the contents of learning material, 4) placement, the results of the evaluation of learning activities are expected to provide an overview of the different levels of student ability. Therefore, these activities are technically expected to be grouped based on different levels of ability and require the holding of learning according to the ability level of each group, based on the interests and talents of students, 5) curriculum, the results of the learning evaluation are also used as feedback, which is to test the contents of the curriculum and the process of implementing learning. In addition, the evaluation process is expected to improve the curriculum, in accordance with technological developments and community demands, 6) institutional assessment, the results of evaluation activities in the learning process, will significantly have a good influence on Islamic educational institutions. This view is expected to have a positive influence in addition to improving the quality of Islamic education in the future in accordance with developments in the era of the industrial revolution 4.0 today.

\section{E. Conclusion}

From broad explanation above, we can conclude that Islamic education such as madrasah play important role in Indonesian education since its existence has given so much contribution. Furthermore, madrasah is expected to advance by following what society needs nowadays. In order to fullfil that goal, the education management of madrasab should be innovated in four components i.e. students, teachers, objectives and learning materials. In addition, it is a must for school management to pay attention to basic aspects that should be existed in a good management i.e. planning, implementing, organizing, and evaluation in order to achieve a qualified learning management.

Other than that, principal is one of the keys to be concerned because his existence becomes very essential to improve quality of human resources such as teachers by providing professionalizm improvement. For example, how to treat students well how to afford for appropriate media as well as how to assess students ideally. Moreover, everything done by a principal should be in line with vision and mission of school including learning planning, objectives, activities, media as well as facilities provided at the school.

At the end, challenges must be existed especially in the case of 4.0 industrial revolution in teaching and learning. Realize it or not, the era of industry 4.0 has influenced in many components of education including in the context of madrasab education. In this case, madrasah is expected to be the place where students can stick on Islamic values while having high frequency of using technology as media in learning without deviating to the exposure of negative sides of technology usage.

\section{BIBLIOGRAPY}

Ahmad Fauzi, A. et. al. (2018). Analysis Study of Parental Choice of Education in The Millenial Era. Nadwa: Jurnal Pendidikan Islam, 12(2), 311-330.

Aithal, P. S. (2015). How an Effective Leadership and Governance Supports to Achieve Institutional Vision, Mission and Objectives. International Journal of Multidisciplinary Research and Development, 2(5), 154-161. 
Ajmain, M. T., Hehsan, A., \& Mohamad, A. M. (2019). Learning and Facilitation (PdPc) Islamic Education in Industrial Revolution 4.0. Journal of Research in Psychology, 1(3), 13-17.

Amin, N., Siswanto, F., \& Hakim, L. (2018). Membangun Budaya Mutu yang Unggul Dalam Organisasi lembaga Pendidikan Islam. Al-Tanzim ; Jurnal Manajemen Pendidikan Islam, 2(1), 1.

Anwar, H. (2018). Implementation of Education Management STandard in the Guidance of Private Islamic High School. Jurnal Pendidikan Islam, 4(1), 75-86.

Badaruddin, A. M. (2018). The Role of Principal in Madrasah Based Management. International Journal of Social Sciences, 65(1), 1-11.

Bafadhal, I. (2014). Perencanaan Pengajaran Berdasarkan Pendekatan Sistem. Jakarta: PT Bumi Aksara. Beckman, S. L., \& Barry, M. (2007). Innovation as a Learning Process: Embedding Design Thinking. California Management Review. https://doi.org/10.2307/41166415

Bolhuis, S., \& Voeten, M. J. M. (2001). Toward Self-directed Learning in Secondary Schools: What Do Teachers Do? Teaching and Teacher Education. https://doi.org/10.1016/S0742051X(01)00034-8

Brews, P. J., \& Hunt, M. R. (1999). Learning to Plan and Planning to Learn: Resolving the Planning School/Learning School Debate. Strategic Management Journal. https://doi.org/10.1002/(SICI)1097-0266(199910)20:10<889::AID-SMJ60>3.0.CO;2-F

Daryanto, D. (2013). Inovasi Pembelajaran Efektif. Bandung: Yrama Widya.

Davidson, N., \& Major, C. H. (2014). Boundary Crossings: Cooperative Learning, Collaborative Learning, and Problem-Based Learning. Journal on Excellence in College Teaching, 3(4).

Emaliana, I. (2017). Teacher-centered or Student-centered Learning Approach to Promote Learning? Jurnal Sosial Humaniora, 10(2), 59-70.

Farikah. (2019). Developing the Students' Character through Literacy Activities in A ChildFriendly School Model. DIN AMIKA ILMU, 19(2), 187-196.

Fatkuroji, F. (2012). Kebijakan Pembelajaran Terpadu dalam Meningkatkan Minat Konsumen Pendidikan. Nadwa, 6(2), 249. https://doi.org/10.21580/nw.2012.6.2.591

Fauzi, A. (2009). Strategi Pengembangan Kurikulum Pendidikan Tinggi Agama Islam Swasta (PTAIS) dalam Meningkatkan Mutu Pendidikan Studi Komparatif di Universitas Muhammadiyah Malang dan Universitas Islam Malang). Universitas Islam Negeri Maulana Malik Ibrahim Malang.

Fauzi, A. (2018). Filsafat Manajemen Pendidikan Islam (Mengurai Benang Kusut Pengelolaan Pendidikan Islam dari Pendekatan Filosofis menuju Praktis). Jogjakarta: Pustaka Pelajar.

Hamalik, O. (2002). Perencanaan Pengajaran Berdasarkan Pendekatan Sistem. Jakarta: Bumi Aksara.

Hanim, Z. (2019). Learning Innovation Management on Effective Classes at SMPIT Cordova Samarinda. DIN AMIKA ILMU, 19(2), 225-236.

Harackiewicz, J. M., Smith, J. L., \& Priniski, S. J. (2016). Interest Matters: The Importance of Promoting Interest in Education. Policy Insights from the Behavioral and Brain Sciences. https://doi.org/10.1177/2372732216655542

Ilyasin, M. (2017). Balanced Scorecard: A Strategy for the Quality Improvement of Islamic Higher Education. DIN AMIKA ILMU, 17(2), 223-236.

Iswan, I. (2015). The Role of Total Quality Management in Improving Teachers' Performance. Jakarta. Karli, H. (2004). Kurikulum Berbasis Kompetensi. Bandung: Bina Media Informasi.

Keller, J. M. (1979). Motivation and Instructional Design: A Theoretical Perspective. Journal of Instructional Development, 2(4), 26-34.

Lee, S. M., Lee, D., \& Kim, Y. S. (2019). The quality management ecosystem for predictive maintenance in the Industry 4 . 0 era. International Journal of Quality Innovation, 5(4), 3. 
Linhares, A. (2009). Innovation in Teaching and Learning through Problem Posing Tasks and Metacognitive Strategies. International Journal of Pedagogical Innovations, 1(1), 53-62. https://doi.org/10.1080/14703290903069019

Loyens, S. M. M., Magda, J., \& Rikers, R. M. J. P. (2008). Self-Directed Learning in ProblemBased Learning and its Relationships with Self-Regulated Learning. Educational Psychology Review, 20(4), 411-427.

Lubis, S. H. (2018). Islamic Religious Education (PAI) Learning Management in the Formation of Student Characters at State Senior High I of Panyabungan. IJLRES - International Journal on Language, Research and Education Studies, 2(3), 369-380.

Muhaimin. (2003). W acana Pengembangan Pendidikan Islam. Yogyakarta: Pustaka Pelajar.

Muhammadi, N., Charil, S., \& Yahya, M. (2015). The Madrasah Leadership, Teacher Performance and Learning Culture to Improve Quality at Madrasah Tsanawiyah Negeri Jakarta of South. Journal of Management and Sustainability, 5(2), 129-145.

Mukhtar, M., Anwar, K., \& Kholilah, E. H. (2019). Benchmarking Head of Madrasah in Doing Madrasah Transformation in Jambi Province. International Journal of Research - Granthaalayah, 7(4), 281-299.

Mulford, B. (2003). School eaders: Challenging Roles and Impact on Teacher and School Effectiveness. OECD Commissioned Paper. Tasmania: University of Tasmania.

Mulugeta, F. (2015). Current and Preferred Institutional Culture Types and Vision, Mission and Objectives of Addis Ababa University. Journal of Education for Development, 4(1).

Mulyadi. (2010). Kepemimpinan Kepala Sekolah dalam Mengembangkean Budaya Mutu. Malang: UIN Maliki Press.

Mulyasa. (2004). Kurikulum Berbasis Kompetensi 2004. Bandung: PT Remaja Rosdakarya.

National Education System. (2003). Act of the Republic of Indonesia Number 20. Jakarta: Kemendikbud.

Nurcholiq, M. (2019). Desain Pengembangan Kurikulum Madrasah Aliyah Unggulan di Era Revolusi Industri 4.0. JURNAL PIWULANG, 1(2), 208-222.

Rahmah, S. (2016). Mengenal sekolah unggulan. Itqan, VII(1), 14.

Rindu, I., \& Ariyanti, A. (2017). Teacher's Role in Managing the Class during Teaching and Learning Process. Script Journal: Journal of Linguistic and English Teaching, 2(1), 83-100.

Rosyada, D. (2017). The Linearity of Madrasah Development in Indonesia. The 3rd International Conference on Education in Muslim Society (ICEMS). Jakarta: UIN Syarif Hidayatullah Jakarta.

Sa'dun. (2016). Model Manajemen Pendidikan Islam Terpadu dalam Upaya Peningkatan Mutu Sekolah. Quality, 4(2), 236-253.

Sardiman. (2001). Mengajar, Interaksi dan Motivasi Belajar. Jakarta: PT Raja Grafindo Persada.

Shahroom, A. A., \& Hussin, N. (2018). Industrial Revolution 4.0 and Education. International Journal of Academic Research in Business and Social Sciences, 8(9), 314-319.

Shamim, S., Cang, S., Yu, H., \& Li, Y. (2016). Management Approaches for Industry 4.0: A Human Resource Management Perspective. IEEE Congress on Evolutionary Computation. Retrieved from https://www.researchgate.net/publication/311251654

Sholikah. (2017). Desan Pengembangan Kurikulum Pendidikan Agama Islam. KUTTAB, 1(September), 168-179.

Sofanudin, A., Rokhman, F., Wasino, W., \& Rusdarti, R. (2016). Quality-Oriented Management of Educational Innovation at Madrasah Ibtidaiyah. Journal of Education and Practice, 7(27), 176-180. 
Sudjana, N. (2000). Dasar Dasar Proses Belajar Mengajar. Bandung: PT Sinar Baru Algensindo. Syafaruddin, S. (2005). Manajemen Lembaga Pendidikan Islam. Jakarta: Ciputat Press.

Tremblay, K, Lalancette, D \& Roseveare, D. (2012), Assessment of Higher Education Learning Outcomes feasibility study report: volume 1 - design and implementation, OECD, Paris

Woods, D. D., \& Cook, R. I. (2002). Nine Steps to Move Forward from Error. Cognition, Technology \& Work. https://doi.org/10.1007/s101110200012

Yusuf, M., Sunardi, S., Rachman, M., \& Haryono, H. (2014). The Development of Inclusive Education Management Model to Improve Principals and Teachers Performance in Elementary Schools. The Journal of Educational Development, 2(2), 154-162.

Zahroh, A. (2014). Manajemen Sekolah Unggulan: Strategi Pengembangan Kapasitas Sekolah Menuju Pendidikan Bermutu. Ta'allum, 2(2), 151-152. 